\title{
Role of Mitochondria in Epilepsy
}

\author{
Massoud Houshmand \\ National Institute for Genetic Engineering and Biotechnology, Tehran, \\ Iran
}

\section{Introduction}

The dramatic clinical presentation of many seizure disorders has been recognized for millennia. Many prominent individuals have been affected including Julius Caesar, James Madison, Peter Tchaikovsky, Alfred Nobel and Leo Tolstoy. Distinguishing types of seizures has helped direct treatment, clarify prognosis and, more recently, provide insight into basic pathophysiology. Clearly, the generic "seizure" involves neuronal dysfunction. Often, there are no physical changes in brain cells. Nutritional and toxic aspects of seizures have been studied in past decades. Perhaps more valuable in terms of cellular biology have been insights gained from examination of well-defined seizure types. Of particular interest has been a group of neuromuscular disorders genetically linked to the mitochondrial genome.

\section{Mitochondrial genetic}

Mitochondria are the powerhouses of our cells. They are responsible for heat production and generating energy as adenosine triphosphate (ATP), therefore mitochondria play a major role in initiating the process of apoptosis. Mitochondria produce more than $90 \%$ of our cellular energy by oxidative phosphorylation (OXPHOS) (Wallace D.C, 1999 and 2005, Gupta, 2001, Spees, J et al 2006) (DiMauro, S., Schon, E. A. 2003). Energy production is the result of two closely coordinated metabolic processes including the tricarboxylic acid (TCA) cycle, also known as the Krebs or citric acid cycle, and the electron transport chain (ETC). The TCA cycle converts carbohydrates and fats into some ATP, but its major job is the capture of electrons by the coenzymes NADH and FADH which shuttle this energy to the ETC. The synthesis of ATP occurs through the respiratory which is located at the inner mitochondrial membrane and consists of five protein complexes (Complexes I-V). Most of the oxygen that is consumed that reduced to water through four consecutive one-electron reductions. (Brookes, P et al. 2004). Current theory holds that mitochondria are the descendants of aerobic bacteria that colonized an ancient prokaryote between 1 and 3 billion years ago (Vellai T et al. 1998 and Roger AJ et al. 1996).

A single somatic cell can contain from of 200 to 2000 mitochondria (Veltri K et al 1990 and Gray M.W, et al 1989), while human germ cells such as spermatozoa contain a fixed number of 16 mitochondria and oocytes have up to 100000 (Szewczyk A et al 2002). The largest numbers of mitochondria are found in the most metabolically active cells, such as skeletal, cardiac muscle, the liver and brain. Mitochondria are found in every human cell except mature erythrocytes (Cohen, B. H., and Gold, D. R. 2001). 
Mitochondria are controlled by both nuclear and mitochondrial genomes therefore, there are several very unique features of the mitochondrial genome. Mitochondrial DNA comprises 0.1$2 \%$ of the total DNA in most mammalian cells. MtDNA consists of a $16.5 \mathrm{~kb}$ doublestranded circular DNA molecule that is maternally inherited (Anderson et al. 1981). MtDNA has 2 strands: a guanine-rich heavy strand (or outer strand) and cytosine-rich light strand (or inner strand). The comprision of ETC 13 polypeptide genes can be classified as fallow:

1. MtDNA also encodes the $12 \mathrm{~S}$ and $16 \mathrm{~S}$ rRNA genes, and the 22 tRNA genes, which are required for mitochondrial protein synthesis. MtDNA encodes 7 subunits (ND1, 2, 3, 4, $4 \mathrm{~L}, 5$, and 6) of the 46 subunits constituting complex I, one of 11 subunits of complex III, 3 of 13 subunits of complex IV, and 2 of 17 subunits of complex V (Reddy PH and Beal MF, 2005). The rest of the polypeptides of the ETC complexes, including all the subunits of Complex II (succinate dehydrogenase), as well as approximately 1500 other proteins which function in mitochondria are encoded by nuclear genes, synthesized in the cytosol and imported into mitochondria through various protein import systems.

2. Genetic information is not distributed equally on the two mtDNA strands. The two mtDNA strands can be separated by denaturing cesium chloride gradient centrifugation (Kasamatsu H, and Vinograd J, 1974). Most of the information is encoded in the heavy (purine-rich) strand. The light (pyrimidine-rich) strand contains genetic information for only one polypeptide and eight tRNAs.

3. Mitochondrial genes have no introns and intergenic sequences are absent or limited to a few bases. Some genes overlap and in some instances, termination codons are not encoded (Ojala D, et al., 1981).

4. Human mtDNA is exclusively inherited through the maternal lineage. Mitochondria from spermatozoa penetrate to the ovum but they are selectively marked with ubiquitin and apparently removed (Sutovsky P et al.1999). It has been recently found that even before the elimination of the spermatozoa mitochondria, the mtDNA is degraded (Nishimura Y. et al. 2006).Spermatozoa are germinal cells but the behavior of their mitochondria is similar to that of somatic cells. They are very active (E. Ruiz-Pesini et al 2007)and produce many mutagenic reactive oxygen species (ROS). Thus, by removing the paternal mtDNA, the possibility of transmitting mtDNA mutations decreases enormously. In fact, the only known human paternal contribution to the next generation is associated with a pathologic mutation in the mtDNA (M. Schwartz et al 2002).

5. Mitochondria do not have histones. However, mammalian mtDNA is organized in nucleoids, which can be seen under the microscope as punctuate structures containing mtDNA and proteins which localize to the matrix surface of the mitochondrial inner membrane. Another important piece of information about mtDNA is whether this genome is totally dependent upon nuclear-encoded proteins for its maintenance and transcription. Regarding replication, mtDNA replicates throughout the lifespan of an organism in both proliferating and post-mitotic cells in order to maintain a constant supply of genetic material so that mitochondria can undergo continuous turnover.

6. Mammalian mitochondria have multi-copies of own genome (approximately 103 to 104 copies/cell). Mitochondria which is replicated and expressed within mitochondria (Clayton, 1982, 1984).

7. While the ovum has about 100,000 copies of mtDNA, during oogenesis, the number of mtDNA molecules that will populate the next generation is very small, with estimates ranging as low as one to a few mtDNA genomes (known as the "bottleneck") (Wallace 
DC, et al 2001and Howell N, et al 2000). Thus, a heteroplasmic mother frequently will have children with widely different average levels of mutant heteroplasmy.

8. Unlike nuclear genes in which there are usually two copies per cell, mtDNA is at high copy number with hundreds to tens of thousands of copies per cell (Smeitink J, et al 2001). Thus, while in nuclear genetics there are homozygotes (100\% mutant) and heterozygotes ( $50 \%$ mutant) within mtDNA, mutant proportions can vary anywhere between $0 \%$ and $100 \%$ across the spectrum (e.g., $0.42 \%$ or $78.3 \%$ mutant). When two (and very rarely more) mtDNA sequences coexist in the same mitochondrion, cell, tissue or individual, the term "heteroplasmy" is applied. In clinical diagnostics, one usually discusses heteroplasmy as consisting of a "wild-type" (normal) mtDNA sequence and a "mutant" (disease-associated) mtDNA sequence, although this is not always the case as benign polymorphisms can also be heteroplasmic, in other words, both mtDNA sequences may be unrelated to disease (Tzen CY, et al 2001).

9. A critical number of mutated mtDNAs must be present before tissue dysfunction and clinical signs become apparent, so-called threshold effect. Tissues with high requirements for oxidative energy metabolism, such as muscle, heart, brain, and neurosensory organs have relatively low thresholds and are particularly vulnerable to mtDNA mutations.

\section{Mitochondrial disorders}

Hereditary mitochondrial disorders are caused by mutations in the mtDNA, or nuclear DNA (nDNA), resulting in impaired respiratory chain activity or oxidative phosphorylation. Phenotypically, mitochondrial disorders present as single or multi system diseases, with onset between birth and senescence (Zeviani M, Di DonatoS 2004). Mitochondrial disorders usually have a progressive course which is why single organ affection turns into multisystem affection during the disease course. Mitochondrial disorders manifest in tissues/organs with high-energy demand (Montirosso R, et al.2002) and are aggravated by fever, infection, stress, or certain drugs (Longo N. 2003). Systems/organs most frequently clinically or sub-clinically affected in mitochondrial disorders are the peripheral nervous system, the central nervous system (CNS), endocrine glands, heart, ears, eyes, gastrointestinal tract, liver, kidneys, bone marrow, and dermis (Finsterer J. 2004).Various combinations of organ affection constitute mitochondrial syndromes for which well-known acronyms have been adopted.

The second most frequently affected system is the CNS (Finsterer J et al 2001). Similar to other organs, the CNS may be affected alone or together with one or several other tissues. Most frequently the CNS is affected together with the skeletal muscles for which the term _encephalomyopathy_was coined (Riggs JE, et al 1984, Leonard JV, Schapira AHV 2000).

The frequency of mtDNA diseases is high. It has been estimated that one out of approximately 8000 individuals harbors a pathogenic mtDNA mutation (Chinnery P.F. et al 2000). Mitochondrial diseases are mostly caused by defects in the enzymes involved in respiration and OXPHOS (Wallace D.C, 1999 and 2005, Gupta, 2001, Spees, J et al 2006, DiMauro, S., Schon, E. A 2003). They may arise from mutations in nuclear DNA or mtDNA. It has been documented that some mitochondrial diseases are caused by specific mutations in nuclear genes, which are involved in the replication and maintenance of mtDNA and respiratory chain function of mitochondria. These diseases may be resulted from defects in the citric acid cycle, $\beta$-oxidation of fatty acids, the urea cycle, and the respiration and OXPHOS system, respectively. 
A striking feature of mtDNA disorders is their clinical heterogeneity, ranging from singleorgan involvement to severe multisystem disease. The same mutation or different mutations in the same mtDNA gene may present with very different clinical manifestations while the same clinical phenotype may be caused by different mutations.

This variability in clinical manifestation may be due to several factors, including the ratio of wild-type to mutant mtDNA, varying thresholds of biochemical expression for both the mutation and the tissue involved, and the modulating effect of nuclear and other mitochondrial genes. Since 1988, more than 100 distinct mtDNA point mutations have been identified in patients with diverse clinical phenotypes (Schon EA, et al 2002. and Servidei S, 2002).

\begin{tabular}{|l|l|}
\hline $\begin{array}{l}\text { Organ } \\
\text { system }\end{array}$ & Possible symptom or disease \\
\hline Muscles & Hypotonia, weakness, cramping, muscle pain, ptosis, opthalmoplagia \\
\hline Brain & $\begin{array}{l}\text { Developmental delay, mental retardation, autism, dementia, seizures, } \\
\text { neuropsychiatric disturbances, atypical cerebral palsy, atypical migraines, } \\
\text { autism, and stroke like events }\end{array}$ \\
\hline Nerves & $\begin{array}{l}\text { Neuropathic pain and weakness, acute and chronic inflammatory } \\
\text { demyelinating polyneuropathy, absent deep tendon reflexes, neuropathic } \\
\text { gastrointestinal problem, fainting, absent or excessive sweating aberrant } \\
\text { temperature regulation }\end{array}$ \\
\hline Kidneys & $\begin{array}{l}\text { Proximal renal tubular dysfunction: possible loss of protein, magnesium, } \\
\text { phosphorus, calcium, and other electrolytes }\end{array}$ \\
\hline Heart & Cardiac conduction defects, cardiomyopathy \\
\hline Liver & Hypoglycemia, gluconeogenic defects, nonalcoholic liver failure \\
\hline Eyes & Optic neuropathy and retinitis pigmentosa \\
\hline Ears & Sensorineural hearing loss, aminoglycoside sensitivity \\
\hline Pancreas & Diabetes and exocrine pancreatic failure \\
\hline Systemic & $\begin{array}{l}\text { Failure to gain weight, short stature, fatigue, respiratory problems } \\
\text { including intermittent air hunger }\end{array}$ \\
\hline
\end{tabular}

Table 1. Signs, symptoms and diseases associated with mitochondrial dysfunction

\section{Myopathies}

1. Chronic progressive external ophthalmoplegia (CPEO), with or without retinitis pigmentosa or limb weakness and fatigue, is the commonest clinical manifestation of an OXPHOS mtDNA defect. The age of onset is usually during the second or third decades but late-onset mitochondrial myopathy is well recognized. The clinical course is usually benign in that additional tissue or organ failure rarely develops and the risk of serious disability is very low.

2. Kearns-Sayre syndrome (KSS) is a subtype of CPEO with onset before age 20 and one of the following: cardiac conduction defects, cerebellar ataxia or CSF protein greater than $100 \mathrm{mg} / \mathrm{dl}$. Some patients have additional manifestations, including dementia or endocrinopathies. These patients may develop additional features such as deafness, diabetes, endocrine dysfunction, and behavioural disorders. The prognosis is much worse than that for isolated CPEO, and few patients survive beyond the age of 30 . Isolated limb myopathy is a frequent manifestation of mtDNA disorders, taking the 
form of a proximal limb weakness with fatigue. Deterioration is usual but it is slow and the patient is unlikely to need a wheelchair. This spectrum of phenotypes is often caused by a single large mtDNA deletion, especially the 5-kb "common deletion", but additional possibilities include deletion/duplications and mtDNA point mutations including A3243G (Wallace DC, et al 2001).

\section{Leber's hereditary optic neuropathy (LHON)}

1. LHON is the commonest cause of blindness in healthy young men. It is maternally inherited and manifests in late adolescence or early adulthood as bilateral sequential visual failure. $90 \%$ of patients are affected by age 40 and virtually all by age 50 . Although the disease is usually confined to the optic nerve some patients also have cardiac conduction defects or encephalopathic features, particularly dystonia. The preponderance of males (about 80\%) among LHON patients and the high proportion of symptomless carriers have prompted the suggestion that factors other than mtDNA mutations contribute to pathogenesis. LHON is usually caused by homoplasmic mtDNA mutations (100\% mutant); the most common are G11778A, G3460A and T14484C (Wallace DC, et al 2001). Penetrance is low, and males are three to four times more likely to become blind than females.

\section{Encephalomyopathies}

Any combination of encephalopathic features (dementia/mental retardation, ataxia, seizures, myoclonus, deafness, dystonia) may occur alone, in combination, or in association with myopathy. However, certain syndromes have emerged that remain a useful means for classification even though the syndromes may overlap considerably.

1. Mitochondrial encephalopathy, lactic acidosis and stroke-like episodes (MELAS) is probably the commonest of the mitochondrial encephalomyopathies. This syndrome is characterized by stroke-like episodes, often reversible, with onset generally between age 5-15 years but can be anywhere between infancy and adulthood. Most cases are caused by heteroplasmy for the A3243G mutation; however, T3271C, other heteroplasmic mtDNA point mutations, large rearrangements and presumed nuclear defects (with normal mtDNA) can cause the MELAS phenotype. Ragged-red fibers and abnormal electron transport chain activities are frequently absent, particularly in younger children. Although the A3243G mutation is usually thought of as being causal for MELAS, the mutation is more often associated with maternally inherited diabetes, deafness, cognitive impairment, short stature and/or migraine, as well as a wide variety of other disease manifestations (Wallace DC, et al 200; Shah NS, et al 2002; Harrison TJ, et al 1997; and Majamaa K, et al 1998).

2. Leigh syndrome_Also called subacute necrotizing encephalopathy, this disorder is characterized by cranial nerve abnormalities, respiratory dysfunction and ataxia with hyperintense signals on T2-weighed images in the basal ganglia, cerebellum or brain stem. Age of onset is from infancy to early childhood. As in many other mitochondrial disorders, Leigh disease is usually but not always progressive and lethal, and progression often occurs associated with infection. There is significant genetic heterogeneity, including mutations on both genomes. Very high mutant loads of the T8993G/C mtDNA mutation (usually > 95\%) are one common cause of Leigh syndrome. The most common nuclear DNA related causes of Leigh disease are complex I deficiency (including NDUFV1 mutations), complex IV deficiency (including SURF1 mutations), and PDHC deficiency (Wallace DC, et al 2001). 
3. Myoclonic epilepsy and ragged-red fiber disease (MERRF) this syndrome consists of progressive epilepsy and dementia, with onset in late childhood or adulthood. Most cases have heteroplasmy for $\mathrm{A} 8344 \mathrm{G}$, a point mutation in the tRNA lysine gene. Some patients have multiple symmetrical lipomatosis, which are large subcutaneous fat masses, usually located around the neck (Shoffner JM. 2001). Ragged-red fibers refer to subsacrolemmal collections of mitochondria that stain red on modified Gomori trichrome stain. They are present in many patients with different presentations of mitochondrial disease but are not common in affected children. Myoclonus may occur in association with generalized seizures. The prognosis is variable but a useful pointer is the mutant load in the blood.

\begin{tabular}{|l|l|}
\hline Syndrome & Symptom \\
\hline Kearn-Sayre Syndrome (KSS) & $\begin{array}{l}\text { External ophtalmoplegia, cardiac conduction } \\
\text { defects, and sensorineural hearing loss }\end{array}$ \\
\hline $\begin{array}{l}\text { Leber hereditary optic neuropathy } \\
\text { (LHON) }\end{array}$ & Visual loss in young adulthood \\
\hline $\begin{array}{l}\text { Mitochondrial encephalomyopathy, } \\
\text { lactic acidosis, and stroke-like } \\
\text { syndrome (MELAS) }\end{array}$ & $\begin{array}{l}\text { Varying degrees of cognitive impairment and } \\
\text { dementia, lactic acidosis, strokes, and transient } \\
\text { ischemic attacks }\end{array}$ \\
\hline $\begin{array}{l}\text { Myoclonic epilepsy and ragged-red } \\
\text { fibers (MEERF) }\end{array}$ & $\begin{array}{l}\text { Progressive myoclonic epilepsy, clumps of } \\
\text { diseased mitochondria accumulate in the } \\
\text { subsarcolemmal of the muscle fibers }\end{array}$ \\
\hline $\begin{array}{l}\text { Leigh syndrome subacute sclerosis } \\
\text { encephalopathy }\end{array}$ & $\begin{array}{l}\text { Seizures, altered states of consciousness, } \\
\text { dementia, ventilator failure }\end{array}$ \\
\hline $\begin{array}{l}\text { Neuropathy, ataxia, retinitis, } \\
\text { pigmentosa, and ptosis (NARP) }\end{array}$ & $\begin{array}{l}\text { Dementia, in addition to the symptoms described } \\
\text { in the acronym }\end{array}$ \\
\hline $\begin{array}{l}\text { Myoneurogenic gastrointestinal } \\
\text { encephalopathy (MINGIE) }\end{array}$ & Gastrointestinal pseudo-obstruction, neuropathy \\
\hline
\end{tabular}

Table 2. Inherited conditions in which mitochondrial dysfunction has been implicated

\section{Mitochondrial Investigation}

1. Biochemistry:_Blood lactate concentrations and lactate: pyruvate ratios may be increased at rest and rise significantly above those for matched controls after exercise. In patients with encephalopathy, particularly in infants, CSF lactate may be raised. Creatine kinase levels are either normal or only mildly increased. Biochemical analysis of isolated mitochondria or muscle tissue by enzyme studies, polarography, or spectroscopy may identify the site(s) of the defect within the respiratory chain and this can help to direct molecular genetic analysis.

2. Electrophysiology:_The electromyogram is normal or only mildly myopathic while nerve conduction studies may demonstrate a peripheral (predominantly axonal) neuropathy.

3. Imaging:_Cranial computed tomography demonstrates cerebral and cerebellar atrophy in many encephalopathic patients; basal ganglia calcification may be seen in MELAS. Magnetic resonance imaging in MELAS-associated stroke reveals increased T2 weighted signals in the grey and white matter, typically of the occipital or parietooccipital areas. Symmetrical changes in the basal ganglia and brainstem are frequently observed in those with Leigh syndrome.

4. Histology:_Muscle biopsy is diagnostic, although occasional patients, with mitochondrial myopathy due to mtDNA mutations and those with LHON may have normal biopsies. 
Histochemical analysis typically reveals ragged red fibers on Gomoritrichrome staining and these fibers stain strongly for succinate dehydrogenase (SDH, complex II). These fibers often stain negatively for COX (complex IV) in CPEO, KSS, or MERRF but positively in MELAS. Maternally inherited Leigh syndrome patients or others presenting in infancy may have no ragged red fibers and demonstrate COX-negative fibers only.

5. Molecular genetics:_Whilst muscle biopsy may prove diagnostic clinically, molecular genetic analysis is necessary for genetic counseling. MtDNA rearrangements are not usually found in blood whilst point mutations are; both types are seen in muscle. Thus a negative result for mutation analysis of mtDNA in blood does not exclude mitochondrial OXPHOS disease. Single mtDNA deletion is the commonest mutation identified in patients presenting in adolescence or adulthood. These mutations are seen most frequently in CPEO with or without myopathy and in KSS although they may occasionally be identified in patients with other phenotypes, including MELAS. mtDNA duplications often accompany deletions and may represent an intermediate stage from the wild-type molecule to deletion although their pathogenicity is uncertain. mtDNA tRNA mutations are probably the commonest of the single base change abnormalities. A3243G (A->G transition at bp 3243) in the tRNALeu(UUR) gene is most frequently found in MELAS and G8344A in tRNALys in MERRF. Many other tRNA mutations have been associated with other clinical phenotypes. Again, there is no strict relation between phenotype and genotype. The primary mutations associated with LHON (G11778A, G3460A, T14484C) are in complex I genes ND4, ND1, and ND6, respectively. G11778A is by far the commonest mutation and is found in over $50 \%$ of LHON families in the UK. A variety of secondary mutations may cause LHON if present in combination but only the primary ones seem capable of causing LHON on their own. The mutations are distributed in all tissues and are present in blood in high load, often being homoplasmic.

However, a systematic search for new mtDNA mutations is usually undertaken only in highly selected patients, when there is a strong indication that symptoms are attributable to a mitochondrial defect and the trait is transmitted maternally (Houshmand et al 1994)

\begin{tabular}{|l|l|l|}
\hline Phenotype & Mutation & Gene \\
\hline LHON & $3460 \mathrm{G}->\mathrm{A}$ & MT-ND1 \\
\hline & $11778 \mathrm{G}->\mathrm{A}$ & MT-ND4 \\
\hline & $14484 \mathrm{~T}->\mathrm{C}$ & MT-ND6 \\
\hline Leigh, NARP & $8993 \mathrm{~T}->\mathrm{G}$ & MT-ATP 6 \\
\hline MELAS, Diabetes & $3243 \mathrm{~A}->\mathrm{G}$ & MT- TL1 \\
\hline MERRF & $8344 \mathrm{~A}->\mathrm{G}$ & MT-TK \\
\hline Non syndromic deafness & $1555 \mathrm{~A}->\mathrm{G}$ & MT-RNR1 \\
\hline
\end{tabular}

Table 3. Mitochondrial DNA Mutations frequently associated to specific phenotype MITOMAP: A Human Mitochondrial Genome Database. http:/ / www.mitomap.org

\section{Mitochondrial epilepsy}

The genetic forms of progressive myoclonus epilepsies (PMEs) are a clinically variable and causally rare heterogenous group, mostly autosomal recessive disorders. The exceptions to 
autosomal recessive mode of inheritance are autosomal dominant dentatorubralpallidoluysian atrophy and MERRF.

\begin{tabular}{|c|c|c|c|}
\hline Model & Samples & Experimental findings & Reference \\
\hline $\begin{array}{l}\text { kainic acid, } \\
\text {-treated rats }\end{array}$ & $\begin{array}{l}\text { Hippocampal } \\
\text { slices }\end{array}$ & $\begin{array}{l}\text { Increased basal energy } \\
\text { turnover with glucose as } \\
\text { substrate Higher uncoupled } \\
\text { rate of respiration }\end{array}$ & $\begin{array}{l}\text { Kunz } \\
\text { et al.( } 1999\end{array}$ \\
\hline $\begin{array}{l}\text { Temporal lobe } \\
\text { epilepsy (human) }\end{array}$ & $\begin{array}{l}\text { Hippocampal } \\
\text { specimens }\end{array}$ & $\begin{array}{l}\text { Mitochondrial Complex I } \\
\text { deficiency and ultrastructural } \\
\text { abnormalities of } \\
\text { mitochondria in the epileptic } \\
\text { focus }\end{array}$ & $\begin{array}{l}\text { Kunz } \\
\text { et al.(2000 }\end{array}$ \\
\hline $\begin{array}{l}\text { Perforant path } \\
\text { stimulation model } \\
\text { of rats }\end{array}$ & $\begin{array}{l}\text { Whole brain } \\
\text { tissues }\end{array}$ & $\begin{array}{l}\text { Reduction of brain aconitase } \\
\text { and <-ketoglutarate dehydro } \\
\text { genase activities } \\
\text { Decrease in reduced } \\
\text { glutathione levels }\end{array}$ & $\begin{array}{l}\text { Cock } \\
\text { et al.(2002 }\end{array}$ \\
\hline $\begin{array}{l}\text { Pilocarpine-treated } \\
\text { rats }\end{array}$ & $\begin{array}{l}\text { Hippocampal } \\
\text { tissues and } \\
\text { slices }\end{array}$ & $\begin{array}{l}\text { Decline of the activities of } \\
\text { Complexes I and IV and } \\
\text { lower } \\
\text { mitochondrial membrane } \\
\text { potential in CA1 and CA3 } \\
\text { sub } \\
\text { fields } \\
\text { Decrease in mitochondrial } \\
\text { DNA copy number in CA3 }\end{array}$ & $\begin{array}{l}\text { Kudin } \\
\text { et al.(2002 }\end{array}$ \\
\hline $\begin{array}{l}\text { Perforant path } \\
\text { stimulation model } \\
\text { of rats }\end{array}$ & $\begin{array}{l}\text { Hippocampal } \\
\text { tissues }\end{array}$ & $\begin{array}{l}\text { Reductions in glutathione, <- } \\
\text { ketoglutarate dehydrogenase, } \\
\text { aconitase, citrate synthase, } \\
\text { and Complex I activities }\end{array}$ & $\begin{array}{l}\text { Gibbs } \\
\text { et al.(2006 }\end{array}$ \\
\hline $\begin{array}{l}\text { Pilocarpine-treated } \\
\text { rats }\end{array}$ & $\begin{array}{l}\text { Hippocampal } \\
\text { tissues }\end{array}$ & $\begin{array}{l}\text { Depression of mitochondrial- } \\
\text { and nuclear-encoded COX } \\
\text { activity and COX III } \\
\text { expression } \\
\text { Mitochondrial ultrastructural } \\
\text { damage }\end{array}$ & $\begin{array}{l}\text { Gao } \\
\text { et al.(2007 }\end{array}$ \\
\hline $\begin{array}{l}\text { Intracerebroventricular } \\
\text { infusion of } \\
\text { homocysteic } \\
\text { acid in rats }\end{array}$ & $\begin{array}{l}\text { Cerebral } \\
\text { cortex }\end{array}$ & $\begin{array}{l}\text { Mitochondrial Complex I } \\
\text { inhibition }\end{array}$ & $\begin{array}{l}\text { Folbergrová } \\
\text { et al.(2007 }\end{array}$ \\
\hline $\begin{array}{l}\text { Microinjection of KA } \\
\text { into the hippocampus } \\
\text { of rats }\end{array}$ & $\begin{array}{l}\text { Hippocampal } \\
\text { tissues }\end{array}$ & $\begin{array}{l}\text { Dysfunction of Complex I in } \\
\text { the mitochondrial electron } \\
\text { transport chain and } \\
\text { mitochondrial ultrastructural } \\
\text { injury }\end{array}$ & $\begin{array}{l}\text { Chuang } \\
\text { et al.(2004 }\end{array}$ \\
\hline
\end{tabular}

Tabela 4. Evidences of mitochondrial dysfunction following epileptic seizures from animal and human studies 
Only a few mtDNA pathologic point mutations account for the majority of cases. An interesting common feature of these mutations is that they are usually associated with very well-defined phenotypes, although some particular mtDNA mutations are associated with very different phenotypes.

Epilepsy is also a frequent CNS manifestation of mitochondrial disorders (Abu-Amero KK, et al/2005; Patel MN, 2002; Tsuji M, et al. 2003). Epilepsy may start at infancy as infantile spasms (Blanco-Barca O. et al. 2004; Desguerre I, et al. 2003; Shah NS, et al. 2002), West syndrome (Tsuji M, et al. Blanco-Barca O. et al. 2004), myoclonic jerks (Van Goethem G, et al. 2003; Arenas J, et al. 1999; Casali C, et al. 1999), astatic seizures (Toyono M, et al. 2001), or juvenile myoclonic epilepsy (Minassian BA, et al.1995). In adultpatients myoclonic jerks or focal or generalized epilepsy may occur (Arenas J, et al. 1999;, Mitani M, et al. 2000). In single cases epilepsy a partial is continua have been reported (Balestri P, Grosso S. 2000). Epilepsy is particularly prevalent inpatients with MELAS, MERRF, LS, or NARP. Epidemiological studies have shown that epilepsy patients are more likely to have affected mothers than fathers.

It is a well-known fact that epileptic seizures can be presenting signs of mitochondrial dysfunction in the central nervous system. Thus, generalized seizures have been observed in several forms of myoclonus epilepsy associated with mutations in the mitochondrial DNA polymerase $\gamma$ (POLG) (Naviaux and Nguyen 2004; Zsurka et al. 2008), mitochondrial tRNALys (MT-TK) (Shoffner et al. 1990; Zeviani et al. 1993) and tRNAPhe (MT-TF) (Zsurka et al.2010) genes. Partial seizures are frequently noticed in mitochondrial encephalopathies, including the MELAS syndrome, associated with mutations in the mitochondrial tRNALeu gene (MT-TL1) (Goto et al. 1990). More recently, evidence for a more general involvement of mitochondria also in sporadic forms of epilepsy has been accumulated (Kann et al. 2005; Kunz et al. 2000; Kunz 2002). This might be related to the fact that mitochondria are intimately involved in pathways leading to neuronal cell death (Krajewski et al. 1999; Blümcke et al. 1999) as seen in experimental and human epilepsy. On the other hand, more recent data substantiate the evidence, that mitochondrial dysfunction might play a direct pathogenic role in the process of epileptogenesis and seizure generation in certain types of epilepsy.

\begin{tabular}{|l|l|l|l|l|l|l|l|l|l|l|l|l|l|}
\hline Syndrome & PSY & NPD & SLE & MIG & EPI & EPS & SPS & ATX & HYP & HRM & DRT & DPG & NYS \\
\hline MELAS & + & + & + & + & + & - & - & + & - & + & - & - & - \\
\hline MERRF & + & + & + & - & + & - & + & + & - & + & + & - & - \\
\hline LS & + & + & - & + & + & + & + & + & + & - & - & - & + \\
\hline LHON & + & - & - & - & - & + & - & - & - & - & - & - & - \\
\hline KSS & + & + & + & - & - & - & - & + & - & + & - & + & - \\
\hline NARP & + & + & - & - & + & - & - & + & - & - & - & - & - \\
\hline
\end{tabular}

CNS, central nervous system; PSY, psychiatric abnormalities; NPD, neuropsychological deficits; SLE, stroke-like-episodes; MIG, migraine; EPI, epilepsy; EPS, extrapyramidal manifestations; SPS, spasticity, hyperreflexia; ATX, ataxia; HYP, muscle hypotonia; HRM, hypopituitarism; DRT, dysarthria; DPG, dysphagia; NYS, nystagmus; MELAS, mitochondrial encephalomyopathy, lactic acidosis, stroke-like episodes; MERFF, myoclonic epilepsy and ragged red fibers; LS, Leigh syndrome, maternally inherited Leigh syndrome; LHON, Leber's hereditary optic neuropathy; KSS, Kearns-Sayre syndrome; NARP, neurogenic muscle, weakness, ataxia, and retinitis pigmentosa;

Tabela 5. CNS manifestations of syndromic mitochondrial disease 
The clinical syndrome was first recognized by Fukuhara et al.(1980), when he described the "canonical" signs of 1) myoclonus, 2) generalized tonic clonic and absence seizures, 3) ataxia, and 4) ragged red fibres in the muscle biopsy. MERRF usually starts in childhood but it is not uncommon in adults. Deafness in PME should make one consider MERRF, especially if dementia, dysarthria short stature, optic atrophy, neuropathy, lactic acidosis, hypoventilation, and migraine are present. Inheritance is consistent with mitochondrial (maternal) transmission. Muscle biopsy demonstrates subsarcolemmal aggregates of mitochondria, the so-called ragged-red Fibres. Giant visual evoked potentials are recorded in all cases. Shoffner et al. (1990) were the first to demonstrate the typical A-to-G substitution at nucleotide 8344 in the mitochondrial DNA, which affects the pseudouridine loop of the mitochondrial tRNALys. The A8344G mutation is present in $90 \%$ of patients with MERRF. Two other mutations (T8356C and G8363A) in the tRNAlys gene have also been associated with MERRF. How these mutations produce the disease phenotype is unclear, although it is suspected to be a defect of oxidative energy production.

\begin{tabular}{|c|c|c|c|c|c|c|}
\hline Syndrome & tRNA & Protein & $\begin{array}{c}\text { Single } \\
\text { Deletion }\end{array}$ & $\begin{array}{c}\text { Multiple } \\
\text { Deletion }\end{array}$ & Duplication & nDNA \\
\hline MELAS & + & + & + & + & - & - \\
\hline MERRF & + & - & - & + & - & + \\
\hline LS & + & + & - & - & - & + \\
\hline LHON & - & + & - & - & - & - \\
\hline KSS & - & - & + & + & + & - \\
\hline NARP & - & + & - & - & - & - \\
\hline
\end{tabular}

MELAS, mitochondrial encephalomyopathy, lactic acidosis, stroke-like episodes; MERFF, myoclonic epilepsy and ragged red fibers; LS, Leigh syndrome, maternally inherited Leigh syndrome; LHON, Leber's hereditary optic neuropathy; KSS, Kearns-Sayre syndrome; NARP, neurogenic muscle, weakness, ataxia, and retinitis pigmentosa;

Table 6. Genetic heterogeneity of mitochondrial disease with CNS involvements

MERRF syndrome is a devastating neuromuscular disorder characterized by myoclonic epilepsy, general weakness, muscle wasting, cerebellar ataxia, deafness, and dementia transmitted through maternal lineages (Shoffner JM et al 1990). Additional manifestations such as short stature, optic atrophy, peripheral neuropathy, cardiomyopathy, myoglobinuria, and renal tubular dysfunction have also been documented (ErolI et al 2009) Common clinical manifestations include myopathy, neuropathy, hearing loss, dementia, short stature, and optic atrophy. Less commonly, cardiomyopathy, pigmentary retinopathy, pyramidal signs, ophthalmoparesis, multiple lipomas, and diabetes mellitus can occur. (Chinnery PF et al. 1997)There is an overlap with the syndrome of MELAS, but MERRF usually has a longer course and is associated with milder behavioural and cognitive deficits. (DiMauro S et al. 2002)

In patients with MERRF, the EEG shows generalised spike-and-wave discharges at 2-5 Hz, with background slowing that progress as the disease advances. Focal epileptiform discharges can also be seen.(So N. et al. 1989) Muscle biopsy shows ragged red fibres in over $90 \%$ of patients. ( Hirano M et al 1996) Biochemical studies of respiratory-chain enzymes in 
muscle extracts usually show decreased activity.( Boulet L et al. 1992) Besides, lactate and pyruvate are commonly elevated in serum at rest and increased excessively after moderate physical activities (Ozawa M et al 1995). Brain MRI may show brain atrophy and basal ganglia calcifications. (DiMauro $S$ et al. 2002) Grey-matter signal changes on T2-weighted images are sometimes seen, with deep cerebral nuclei being more involved than the cerebral cortex. When signal changes are seen in the white matter, the peripheral white matter is the earliest to beinvolved. (BarkovichAJ et al 1993). When myoclonus and myoclonic seizures are combined with deafness, ataxia, and neuromyopathy, MERRF should be considered.

\begin{tabular}{|c|c|c|c|c|c|c|c|c|c|}
\hline Syndrome type & $\begin{array}{l}\text { Age at } \\
\text { onset } \\
\text { Year }\end{array}$ & Seizures at onset & Visual & Cerebellar & $\begin{array}{l}\text { Pyramidal } \\
\text { tract }\end{array}$ & $\begin{array}{l}\text { Extrapyramidal } \\
\text { tract }\end{array}$ & Dementia & Neuropathology & Death \\
\hline $\begin{array}{l}\text { Mitochondrial } \\
\text { encephalomyopathy } \\
\text { with } \\
\text { ragged-red } \\
\text { fibers or } \\
\text { MERRF }\end{array}$ & $3 \pm 65$ & $\begin{array}{l}\text { Photosensitive } \\
\text { generalized or } \\
\text { partial seizures } \\
\text { with } \\
\text { lactic acidosis and } \\
\text { neuromyopathy, } \\
\text { short stature, and } \\
\text { migraine, deafness }\end{array}$ & $\begin{array}{l}\text { Rare optic } \\
\text { atrophy }\end{array}$ & Can occur & $\begin{array}{l}\text { Dysarthria } \\
\text { ataxia }\end{array}$ & No & $\begin{array}{l}\text { Slowly } \\
\text { progressive }\end{array}$ & $\begin{array}{l}\text { Ragged-red fibers on } \\
\text { muscle biopsy; } \\
\text { abnormality in mito } \\
\text { chondrial respiratory } \\
\text { chain consisting of a } \\
\text { heteroplasmic A16 } \\
\text { mutation in position } \\
8.344 \text {; treatment } \\
\text { with } \\
\text { coenzyme Q }\end{array}$ & $\begin{array}{l}3 \pm 30 \\
\text { years } \\
\text { from } \\
\text { onset }\end{array}$ \\
\hline
\end{tabular}

Table 7. Spectrum of MERRF Syndrome

Debilitating if not fatal, these epileptic encephalopathies are characterized by the triad of myoclonus, epilepsy, and progressive neurologic deterioration. Myoclonus or myoclonias consist of stimulus sensitive, segmental or par cellar, arrhythmic, and asynchronous lightning like muscular jerks that affect any muscle group in the body. Epilepsy is also stimulus sensitive and consists of generalized tonic \pm clonic or clonic \pm tonic \pm clonic seizures (grand mal) and absences. Neurologic deterioration consists of mental decline leading to dementia, cerebellar ataxia, and various progressive neurologic manifestations, depending on the cause.

\section{Genetics and diagnosis}

The most common molecular defect is an adenosine to guanine substitution at nucleotide pair $8344(8344 \mathrm{~A} \rightarrow \mathrm{G})$ in the tRNALys gene of mitochondrial DNA. (Shoffner JM et al 1990) Although few less frequent point mutations of mtDNA were also found in MERRF patients (Virgilio R et al 2009, and Blakely EL et al 2009). Besides, molecular genetic studies of several MERRF pedigrees and biochemical studies of skin fibroblasts showed a positive correlation between the A8344G mutation in the tRNALys gene of mtDNA and the reduction in the activities of respiratory enzyme Complexes I and IV (James AM et al. 1996 and 1999).

Another rare identified molecular cause of MERRF is a tyrosine to cytosine substitution $(8356 \mathrm{~T} \rightarrow \mathrm{C}$ ) in the same gene, (Silvestri G et al. 1992) and another is a guanine to adenosine substitution $(8363 \mathrm{G} \rightarrow \mathrm{A})$. (Santorelli FM et. Al 1996) However, in some individuals, a mutation has not been identified. Clinical clues to the presence of MERRF include deafness, optic atrophy, myopathy, lipomas, intrafamilial variation in age of onset, and maternal transmission. Ragged red fibres and mutations in germline DNA (eg, peripheral blood) can be used to confirm the diagnosis. (Hammans SR et al. 1991)

Defects in mitochondrial respiratory enzyme Complexes I and IV accompanied with RRF are the most prominent biochemical defects in the muscle of MERRF patients (Antonická $\mathrm{H}$ et al 1999) 


\begin{tabular}{|c|c|c|c|}
\hline Phenotype & Mitochondrial gene & Mutations & References \\
\hline \multirow[t]{10}{*}{ MELAS } & tRNALeu(UUR) & $\begin{array}{l}\text { A3243G, } \\
\text { T3271C,A3252G, } \\
\text { C3256T,A3260G, } \\
\text { T3291C }\end{array}$ & $\begin{array}{l}\text { (Goto et al., 1990, } \\
\text { 1991,1994; Morten et al., } \\
\text { 1993;Nishino et al., } \\
\text { 1996;Sato et al., 1994) }\end{array}$ \\
\hline & tRNAPhe & G583A & (Hanna et al., 1998) \\
\hline & tRNAVal & G1642A & (Taylor et al., 1996) \\
\hline & tRNAGln & G4332A & (Bataillard et al., 2001) \\
\hline & tRNACys & A5814G & (Manfredi et al., 1995) \\
\hline & tRNALys & $\begin{array}{l}\text { A8296G,T8316C, } \\
\text { T8356C }\end{array}$ & $\begin{array}{l}\text { (Campos et al., 2000; } \\
\text { Sakuta and Nonaka, } \\
\text { 1989; Zeviani et al., } \\
1993 \text { ) }\end{array}$ \\
\hline & COX III & T9957C & (Manfredi et al., 1996) \\
\hline & ND5 & G13513A & (Santorelli et al., 1997) \\
\hline & ND6 & G14453A & (Ravn et al., 2001) \\
\hline & Cyt b & del 14787-90 & (De Coo et al., 1999) \\
\hline \multirow[t]{2}{*}{ MERRF } & tRNALys & A8344G, T8356C & $\begin{array}{l}\text { (Shoffner et al., 1990; } \\
\text { Zeviani et al., 1993) }\end{array}$ \\
\hline & tRNAPhe & G611A & (Mancuso et al., 2004 \\
\hline \multirow[t]{7}{*}{ Atypical MERRF } & tRNALeu(UUR) & G3255A & (Nishigaki et al., 2003) \\
\hline & tRNASer(UCN & 7472 Ins C & (Pulkes et al., 2005) \\
\hline & tRNAAsp & A7543G & (Shtilbans et al., 1999) \\
\hline & tRNALys & G8342A & (Tiranti et al., 1999) \\
\hline & tRNAHis & G12147A & (Taylor et al., 2001) \\
\hline & ND3 & T10191C & (Taylor et al., 2004 \\
\hline & ND5 & G13042A & (Naini et al., 2005) \\
\hline $\begin{array}{l}\text { Seizures, PEO, } \\
\text { diabetes, and deafness }\end{array}$ & tRNALeu(UUR) & A3256G & (Moraes et al., 1993) \\
\hline $\begin{array}{l}\text { Cardiomyopathy, } \\
\text { deafness, and seizures }\end{array}$ & tRNAIle & $\begin{array}{l}\text { A4269G, } \\
\text { C4320T }\end{array}$ & $\begin{array}{l}\text { (Taniike et al., 1992; } \\
\text { Santorelli et al., 1997) }\end{array}$ \\
\hline \multirow{2}{*}{$\begin{array}{l}\text { ME with recurrent } \\
\text { episodes of epilepsia } \\
\text { partialis continua }\end{array}$} & tRNASer(UCN & T7512C & $\begin{array}{l}\text { (Jaksch et al., 1998; } \\
\text { Schuelke et al., 1998) }\end{array}$ \\
\hline & COX I & C6489A & (Varlamov et al., 2002) \\
\hline \multirow[t]{2}{*}{ Leigh syndrome } & ATP6 & T8993G,T8993C & $\begin{array}{l}\text { (Canafoglia et al., 2001; } \\
\text { De Vries et al., 1993) }\end{array}$ \\
\hline & tRNALys & G8363A & (Shtilbans et al., 2000) \\
\hline \multirow[t]{2}{*}{ LHON } & ND1 & G3460A & (Brown et al., 2001) \\
\hline & ND2 & C4640A & (Brown et al., 2001) \\
\hline
\end{tabular}

ME - mitochondrial encephalopathy; MERRF - myoclonus epilepsy with 'ragged redfibers'; MELAS - mitochondrial encephalopathy with lactic acidosis and stroke-likeepisodes; PEO - progressive external ophthalmoplegia; LHON - Leber's hereditaryoptical neuropathy; RC - respiratory chain.

Table 8. Epileptic phenotypes in mitochondrial gene-related mitochondrial disorders. 


\begin{tabular}{|c|c|c|c|}
\hline Type of defect & Biochemical defect & Clinical phenotype & Defective gene \\
\hline \multirow{4}{*}{$\begin{array}{l}\text { Genes altering the } \\
\text { stability of } \\
\text { mitochondrial DNA }\end{array}$} & mtDNA depletion & Alpers syndrome & POLG \\
\hline & mtDNA depletion & $\begin{array}{l}\text { Infantile } \\
\text { encephalopathy } \\
\text { and hepatopathy }\end{array}$ & DGUOK \\
\hline & mtDNA depletion & $\begin{array}{l}\text { Infantile } \\
\text { encephalomyopathy }\end{array}$ & SUCLG1 \\
\hline & $\begin{array}{l}\text { multiple mtDNA } \\
\text { deletions }\end{array}$ & MNIGIE & TYMP \\
\hline \multirow[t]{2}{*}{$\begin{array}{l}\text { Genes encoding } \\
\text { structural } \\
\text { components of } \\
\text { OXPHOS } \\
\text { complexes }\end{array}$} & $\begin{array}{l}\text { complex I } \\
\text { deficiency }\end{array}$ & $\begin{array}{l}\text { Leigh syndrome or } \\
\text { encephalomyopathy }\end{array}$ & $\begin{array}{l}\text { NDUFS1, NDUFS2, } \\
\text { NDUFS3, NDUFS4, } \\
\text { NDUFS6, NDUFS7, } \\
\text { NDUFS8, NDUFV1, } \\
\text { NDUFV2 }\end{array}$ \\
\hline & $\begin{array}{l}\text { complex II } \\
\text { deficiency }\end{array}$ & Leigh syndrome & $\begin{array}{l}\text { SDHA, SDHB, } \\
\text { SDHC, SDHD }\end{array}$ \\
\hline \multirow{5}{*}{$\begin{array}{l}\text { Genes encoding } \\
\text { assembly factors of } \\
\text { OXPHOS complexes }\end{array}$} & $\begin{array}{l}\text { complex I } \\
\text { deficiency }\end{array}$ & Encephalopathy & NDUFA12 \\
\hline & $\begin{array}{l}\text { complex III } \\
\text { deficiency }\end{array}$ & $\begin{array}{l}\text { Encephalopathy, } \\
\text { tubulopathy } \\
\text { and hepatopathy }\end{array}$ & BCS1L \\
\hline & $\begin{array}{l}\text { complex IV } \\
\text { deficiency }\end{array}$ & Leigh syndrome & SURF1 \\
\hline & $\begin{array}{l}\text { complex IV } \\
\text { deficiency }\end{array}$ & $\begin{array}{l}\text { Infantile } \\
\text { cardioencephalo-pathy }\end{array}$ & $\mathrm{SCO} 2$ \\
\hline & $\begin{array}{l}\text { complex IV } \\
\text { deficiency }\end{array}$ & $\begin{array}{l}\text { Infantile encephalo- } \\
\text { pathy }\end{array}$ & SCO1, COX10 \\
\hline \multirow{5}{*}{$\begin{array}{l}\text { Genes encoding } \\
\text { factors involved in } \\
\text { the biogenesis of } \\
\text { mitochondria, } \\
\text { including OXPHOS }\end{array}$} & $\begin{array}{l}\text { Transporter of } \\
\text { carrier proteins }\end{array}$ & $\begin{array}{l}\text { X-linked deafness- } \\
\text { dystonia syndrome }\end{array}$ & DDP1 \\
\hline & Iron exporter & $\begin{array}{l}\text { X-linked } \\
\text { ataxia/sideroblastic } \\
\text { anemia syndrome }\end{array}$ & $\mathrm{ABC7}$ \\
\hline & Iron storage protein & Friedreich's ataxia & FRDA (Frataxin) \\
\hline & $\begin{array}{l}\text { Metalloprotease, } \\
\text { involved in protein } \\
\text { turnover }\end{array}$ & $\begin{array}{l}\text { Hereditary spastic } \\
\text { paraplegia }\end{array}$ & SPG7 (Paraplegin) \\
\hline & $\begin{array}{l}\text { Dynamin-related } \\
\text { protein, possibly } \\
\text { involved in } \\
\text { mitochondrial } \\
\text { fission and fusion }\end{array}$ & $\begin{array}{l}\text { Autosomal dominant } \\
\text { optic atrophy }\end{array}$ & OPA1 \\
\hline
\end{tabular}

Table 9. Epilepsy phenotypes in patients with nuclear gene-related mitochondrial disorders Table modified according to M. Hirano et al. (2008). 


\begin{tabular}{|c|c|c|}
\hline Gene & Protein function & Phenotype \\
\hline \multicolumn{3}{|c|}{ Genes encoding structural components of OXPHOS complexes } \\
\hline NDUFS1 & Complex I & Leigh syndrome \\
\hline NDUFS2 & Complex I & Cardio-encephalomyopathy \\
\hline NDUFS4 & Complex I & Atypical Leigh syndrome \\
\hline NDUFS7 & Complex I & Leigh syndrome \\
\hline NDUFS8 & Complex I & Leigh syndrome \\
\hline NDUFV1 & Complex I & Leukodystrophy, myoclonus, Leigh syndrome \\
\hline SDHA & Complex II & Leigh syndrome \\
\hline SDHB & Complex II & Phaeochromocytoma, cervical paraganglioma \\
\hline$S D H C, S D H D$ & Complex II & Hereditary paraganglioma \\
\hline Synthesis of $\mathrm{C}_{0} \mathrm{O}_{10}$ & Complex I, II, III & Ataxia, myopathy, seizures \\
\hline \multicolumn{3}{|c|}{ Genes encoding assembly factors of OXPHOS complexes } \\
\hline SURF1 & COX assembler & Leigh syndrome \\
\hline SCO1 & COX assembler & Ketacidotic coma, hepatopathy \\
\hline SCO2 & COX assembler & Infantile cardiomyopathy \\
\hline $\operatorname{CON} 10$ & COX assembler & Tubulopathy, leucodystrophy \\
\hline $\operatorname{COX} 15$ & COX assembler & Hypertrophic cardiomyopathy \\
\hline LRPPRC & Putative mtDNA transcript processing factor & Leigh syndrome (French-Canadian) \\
\hline BCS1L & Complex III assembler & $\begin{array}{l}\text { Tubulopathy, encephalopathy, liver failure } \\
\text { GRACILE syndrome }\end{array}$ \\
\hline \multicolumn{3}{|c|}{ Genes altering the stability of mitochondrial DNA } \\
\hline ANT1 & Nucleotide pool & adCPEO \\
\hline C10 ORF2 (Twinkle) & Nucleotide pool & adCPEO \\
\hline POLG1 & mtDNA replication & adCPEO, arCPEO \\
\hline$T P$ & Nucleotide pool & MNGIE \\
\hline DGUOK & Nucleotide pool & MDS, hepato-cerebral form \\
\hline TK2 & Nucleotide pool & MDS, myopathic form \\
\hline DNC & Nucleotide pool & Congenital microcephaly of Amish \\
\hline \multicolumn{3}{|c|}{ Genes encoding factors involved in the biogenesis of mitochondria, including OXPHOS } \\
\hline DDP1 & Transporter of carrier proteins & X-linked deafness-dystonia syndrome \\
\hline$A B C 7$ & Iron exporter & X-linked ataxia/sideroblastic anemia syndrome \\
\hline FRDA (Frataxin) & Iron storage protein & Friedreich's ataxia \\
\hline SPG7 (Paraplegin) & Metalloprotease, involved in protein turnover & Hereditary spastic paraplegia \\
\hline OPA1 & $\begin{array}{l}\text { Dynamin-related protein, possibly involved in } \\
\text { mitochondrial fission and fusion }\end{array}$ & Autosomal dominant optic atrophy \\
\hline TAZ (Tafazzin) & $\begin{array}{l}\text { Homologous to phospholipid acyltransferases, } \\
\text { abnormality of cardiolipin metabolism }\end{array}$ & Barth syndrome \\
\hline
\end{tabular}

GRACILE, Growth Retardation, Aminoaciduria, Cholestasis, Iron overload, Lactacidosis, Early death AdCPEO, autosomal dominant Chronic External Opthalmoplegia ArCPEO, autosomal recessive Chronic External Ophthalmoplegia MNGIE, Mitochondrial Neuro-Gastro-Intestinal Encephalomyopathy MDS, Mitochondrial DNA Depletion Syndrome

Table 10. Clinical-genetic classification of mitochondrisl disorders.

Mitochondrial dysfunction not only decreases the production of ATP but also increases the reactive oxygen species (ROS) generation through the electron leak from the respiratory chain in mitochondria (James AM et al. 1996 and 1999). Consequently, enhanced oxidative stress and oxidative damage have been often observed in the affected tissues of MERRF patients (Bacman SR et al. 2003). Normally, the expression and activity levels of antioxidant enzymes are induced to change so prevent cells from ROS-induced oxidative damage. Longterm exposure to ROS of the affected cells in MERRF patients may initiate and expedite a vicious cycle to result in further increase of ROS production and enhanced oxidative damage to DNA, RNA, lipids, and proteins in mitochondria (Liu CY et al 2009).

Nuclear disease genes associated with mitochondrial disease can be provisionally classified into four groups: (1) genes encoding structural components of OXPHOS complexes; (2) genes encoding assembly factors of OXPHOS complexes; (3) genes altering the stability of mitochondrial DNA; (4) genes encoding factors involved in the biogenesis of mitochondria, including OXPHOS.

A8296G mutation was found in MT-TK and Ahadi et al (2008) suggest that this mutation is a rare polymorphism or may be a pathogenic mutation in combination with other mutations outside of the MT-TK gene. 


\section{Therapy}

Mitochondrial dysfunction has been identified as a potential cause of epileptic seizure and therapy-resistant forms of sere epilepsy. Experimental and human studies have suggested that excessive free radical generation and a deficient antioxidant system are directly or indirectly implicated as taking part in the pathogenesis of epilepsy, resulting in seizure recurrence and resistance to treatment with antiepileptic drugs.

Antiepileptic drugs alter the neuronal oxidative status and increase membrane lipid peroxidation, leading to the increase risk of seizure recurrence. Epileptic patients and experimental animals with the antioxidant supplementations, such as vitamin E, melatonin and resveratrol, improve the oxidative damage in mitochondrial dysfunction. Hence, the antioxidant supply is beneficial for the prevention of mitochondrial dysfunction and recurrence of epilepsy. In addition, the detection of brain oxidative status is important for predicting the prognosis of patients with medication or surgery.

In MERRF patients with secondary cytochrome-c oxidase deficiency intravenous administration of copper has been reported to be beneficial (Ohinata J, et al 2002). Seizures in mitochondrial diseases can be effectively treated with conventional antiepileptic drugs. If possible, however, valproate should be avoided because of its mitochondrial and liver toxicity and its hematological side effects. In addition, carbamazepine or oxcarbamazepine should be avoided because of its liver toxicity and its hematologic side effects, particularly in mitochondrial diseases patients who frequently also manifest with anemia, leucopenia, or thrombocytopenia. Furthermore, carbamazepine and oxcarbamazepine may cause or worsen hyponatriemia, and thus increase the risk of triggering further seizures. According to personal observations, topiramate may worsen wasting in mitochondrial diseases patients with myopathy. The most well tolerated antiepileptic drugs appear to be lamotrigine, gabapentin, lorazepam, and levetirazetam. For acute seizure control intravenous valproate is sometimes inevitable. Other options for intravenous antiepileptic acute therapy are lorazepam or phenytoin. In single cases with resistance to antiepileptic drugs succinate $(6 \mathrm{~g} /$ day) may reduce seizure frequency. Uncinatus crises in MELAS can be effectively resolved with lorazempam.

\section{References}

Abu-Amero KK, Bosley TM, Bohlega S, Hansen E. Mitochondrial T9957C mutation in association with NAION and seizures but not MELAS. Ophthalmic Genet 2005;26:31-6.

Ahadi A. M, Sadeghizadeh M, Houshmand M, Gharagoozli K, Banoei M. M, ShafaShariatPanahai M. An A8296G mutation in the MT-TK gene of a patient with epilepsy - a disease-causing mutation or rare polymorphism?Neurologia i NeurochirurgiaPolska 2008; 42, 3

Antonická H, Floryk D, Klement P, Stratilová L, Hermanská J, Houstková H, Kalous M, Drahota Z, Zeman J, Houstek J (1999) Defective kinetics of cytochrome c oxidase and alteration of mitochondrial membrane potential in fibroblasts and cytoplasmic hybrid cells with the mutation for myoclonus epilepsy with ragged0red fibres (MERRF) at position 8344 nt. Biochem J 3:537-544

Arenas J, Campos Y, Bornstein B et al. A double mutation (A8296G and G8363A) in the mitochondrial DNA tRNA(Lys) gene associated with myoclonus epilepsy with ragged- red fibers. Neurology 1999;52:377-82., 
Bacman SR, Atencio DP, Moraes CT (2003) Decreased mitochondrial tRNALys steady-state levels and aminoacylation are associated with the pathogenic G8313A mitochondrial DNA mutation. Biochem J 15:131-136

Balestri P, Grosso S. Endocrine disorders in two sisters affected by MELAS syndrome. J Child Neurol 2000;15:755-8.

Barkovich AJ, Good WV, Koch TK, Berg BO. Mitochondrial disorders: analysis of their clinical and imaging characteristics. Am J Neuroradiol1993; 14: 1119-37.

Bataillard, M., Chatzoglou, E., Rumbach, L., Sternberg, D., Tournade, A., Lafort, P., Jardel,C., Maisonobe, T., Lombes, A., 2001. Atypical MELAS syndrome associated with anew mitochondrial tRNA glutamine point mutation. Neurology 56, 405-407.

Berkovic SF, Carpenter S, Evans A, et al. Myoclonus epilepsy and ragged-red fibers (MERRF). A clinical, pathological, biochemical, magnetic resonance spectroscopic and positron emission tomographic study. Brain 1989; 112: 1231-60.

Blakely EL, Trip SA, Swalwell H, He L, Wren DR, Rich P, Turnbull DM, Omer SE, Taylor RW (2009) A new mitochondrial transfer RNAPro gene mutation associated with myoclonic epilepsy with ragged-red fibers and other neurological features. Arch Neurol 66:399-402

Blanco-Barca O, Pintos-Martinez E, Alonso-Martin A et al. Mitochondrial encephalomyopathies and West'ssyndrome: a frequently underdiagnosed association. Rev Neurol 2004;39:618-23.

Blümcke I, Zuschratter W, Schewe JC, Suter B, Lie AA, Riederer BM, Meier B, Schramm J, Elger CE, Wiestler OD (1999) J Comp Neurol 414:437-453

Boulet L, Karpati G, Shoubridge EA. Distribution and threshold expression of the tRNALys mutation in skeletal muscle of patients with myoclonic epilepsy and ragged-red fibers (MERRF). Am J Hum Genet 1992; 51: 1187-200

Brookes, P. S., Yoon, Y., Robotham, J. L., Anders, M. W., Sheu, S. S., Calcium, ATP, and ROS: A mitochondrial love hate triangle. Am. J. Physiol. Cell Physiol. 2004, 287, C817833.

Brown, M.D., Zhadanov, S., Allen, J.C., Hosseini, S., Newman, N.J., Atamonov, V.V.,Mikhailovskaya, I.E., Sukernik, R.I.,Wallace, D.C., 2001. Novel mtDNA mutations andoxidative phosphorylation dysfunction in Russian LHON families. Hum. Genet. 109,33-39.

Campos, Y., Lorenzo, G., Martin, M.A., Torregrosa, A., delHoyo, P., Rubio, J.C., Garcia,A., Arenas, J., 2000. A mitochondrial tRNA(Lys) gene mutation (T8316C) in apatient with mitochondrial myopathy, lactic acidosis, and stroke-like episodes.Neuromuscul.Disord. 10, 493-496.

Canafoglia, L., Franceschetti, S., Antozzi, C., Carrara, F., Farina, L., Granata, T., Lamantea,E., Savoiardo, M., Uziel, G., Villani, F., Zeviani, M., Avanzini, G., 2001. Epilepticphenotypes associated with mitochondrial disorders. Neurology 56, 1340 1346.

Casali C, Fabrizi GM, Santorelli FM et al. Mitochondrial G8363A mutation presenting as cerebellar ataxia andlipomas in an Italian family. Neurology 1999;52:1103-4.

Chinnery PF, Howell N, Lightowlers RN, Turnbull DM. Molecular pathology of MELAS and MERRF.The relationship between mutation load and clinical phenotypes.Brain 1997;120: 1713-21.

Chinnery P.F., M.A. Johnson, T.M.Wardell, R. SinghKler, C. Hayes, D.T. Brown, R.W. Taylor, L.A. Bindoff, D.M. Turnbull, The epidemiology of pathogenic mitochondrial DNA mutations, Ann. Neurol. 48 (2000) 188-193. 
Chuang YC, Chang AYW, Lin JW, et al. Mitochondrial dysfunction and ultrastructural damage in the hippocampus during kainic acid-induced status epilepticus in the rat. Epilepsia 2004;45:1202-9.

Clayton DA. Replication of animal mitochondrial DNA. Cell 1982;28:693-705.

Clayton DA. Transcription of the mammalian mitochondrial genome. Annu Rev Biochem 1984;53:573-94.

Cock HR, Tong X, Hargreaves IP, et al. Mitochondrial dysfunction associated with neuronal death following status epilepticus in rat. Epilepsy Res 2002;48:157-68.

Cohen, B. H., Gold, D. R., Mitochondrial cytopathy in adults: What we know so far. Cleve.Clin. J. Med. 2001, 68, 625 - 626, 629-642.

De Coo, I.F., Renier, W.O., Ruitenbeek, W., TerLaak, H.J., Bakker, M., Schägger, H.,Van Oost, B.A., Smeets, H.J., 1999. A 4-base pair deletion in the mitochondrialcytochrome $b$ gene associated with parkinsonism/MELAS overlap syndrome. Ann.Neurol. 45, 130-133.

Desguerre I, Pinton F, Nabbout R et al. Infantile spasms with basal ganglia MRI hypersignal may reveal mitochondrialdisorder due to T8993G mtDNA mutation. Neuropediatrics 2003;34:265-9.

De Vries, D.D., van Engelen, B.G., Gabrels, F.J., Ruitenbeek, W., van Oost, B.A., 1993. Asecond missense mutation in the mitochondrial ATPase 6 gene in Leigh's syndrome.Ann. Neurol. 34, 410-412.

DiMauro S, Hirano M, Kaufmann P, et al. Clinical features and genetics of myoclonic epilepsy with ragged-red fibers. AdvNeurol2002; 89: 217-29.

DiMauro, S., Schon, E. A., Mitochondrial respiratory-chain diseases.N. Engl. J. Med. 2003, $348,2656-2668$.

Erol I, Alehan F, Horvath R, Schneiderat P, Talim B (2009) Demyelinating disease of central and peripheral nervous systems associated with a A8344G mutation in tRNALys. NeuromusculDisord 19:275-278

Finsterer J. Mitochondriopathies. Eur J Neurol 2004;11:163-86.

Finsterer J, Jarius C, Eichberger H. Phenotype variability in 130 adult patients with respiratory chain disorder. J Inherit Metab Dis 2001;24:560-76.

Folbergrová J, Je`sina P, Drahota Z, et al. Mitochondrial complex I inhibition in cerebral cortex of immature rats following homocysteic acid-induced seizures. Exp Neurol 2007;204:597-609.

Fukuhara N, Tokiguchi S, Shirakawa K, Tsubaki T. 1980. Myoclonus epilepsy associated with ragged-red fibres (mitochondrial abnormalities): disease entity or a syndrome? Light and electron microscopic studies of two cases and a review of the literature. J NeurolSci 47:117 \pm 133 .

Gao J, Chi ZF, Liu XW, et al. Mitochondrial dysfunction and ultrastructural damage in the hippocampus of pilocarpine-induced epileptic rat. Neurosci Lett 2007;411:152- 7.

Gibbs JE, Walker MC, Cock HR. Levetiracetam: antiepileptic properties and protective effects on mitochondrial dysfunction in experimental status epilepticus. Epilepsia 2006;47:469-78

Goto Y, Nonaka I, Horai S (1990) A mutation in the tRNA(Leu)(UUR) gene associated with the MELAS subgroup of mitochondrial encephalomyopathies. Nature 348:651-653

Goto, Y., Nonaka, I., Horai, S., 1991. A new mtDNA mutation associated withmitochondrial myopathy, encephalopathy, lactic acidosis and stroke-like episodes (MELAS).Biochim.Biophys.Acta 1097, 238-240.

Goto, Y., Tsugane, K., Tanabe, Y., Nonaka, I., Horai, S., 1994. A new point mutation atnucleotide pair 3291 of the mitochondrial tRNA(Leu(UUR)) gene in a patient 
with mitochondrial myopathy, encephalopathy, lactic acidosis, and stroke-like episodes(MELAS). Biochem. Biophys. Res. Commun. 202, 1624-1630.

Gray, M. W., Origin and evolution of mitochondrial DNA. Annu. Rev. Cell Biol. 1989, 5, 25 50.

Gupta S. Molecular steps of death receptor and mitochondrial pathways of apoptosis. Life Sci. 2001 Nov 9;69(25-26):2957-64. Review.

Hammans SR, Sweeney MG, Brockington M, Morgan-Hughes JA, Harding AE. Mitochondrial encephalopathies: molecular genetic diagnosis from blood samples. Lancet 1991; 337: 1311-13.

Hanna, M.G., Nelson, I.P., Morgan-Hughes, J.A.,Wood, N.W., 1998. MELAS: a new diseaseassociated mitochondrial DNA mutation and evidence for further genetic heterogeneity.J. Neurol. Neurosurg. Psychiatry 65, 512-517.

Harrison TJ, Boles RG, Johnson DR, LeBlond C, Wong LJ. Macular pattern retinal dystrophy, adult-onset diabetes, and deafness: a family study of A3243G mitochondrial heteroplasmy. Am J Ophthalmol 1997;124:217- 21.

Hirano M, DiMauro S. Clinical features of mitochondrial myopathies and encephalomyopathies. In: Lane RJM, ed. Handbook of muscle disease. New York: Marcel Dekker Inc., 1996:479-504.

Hirano M, Kunz WS, DiMauro S (2008) In epilepsy-a comprehensive textbook: mitochondrial diseases. In: Engel J, Pedley TA (eds) Lippincott Williams \& Wilkins, Philadelphia, Vol. III, pp 2621-2630

Houshmand M, Larsson NG, Holme E, Oldfors A, Tulinius MH, Andersen O. Automatic sequencing of mitochondrial tRNA genesin patients with mitochondrial encephalomyopathy. BiochimBiophysActa 1994;1226:49-55.

Howell N, Chinnery PF, Ghosh SS, Fahy E, Turnbull DM. Transmission of the human mitochondrial genome. Hum Reprod 2000;15(Suppl. 2):235- 45.

Jaksch, M., Klopstock, T., Kurlemann, G., Dörner, M., Hofmann, S., Kleinle, S., Hegemann,S., Weissert, M., Müller-Höcker, J., Pongratz, D., Gerbitz, K.D., 1998. Progressivemyoclonus epilepsy and mitochondrial myopathy associated with mutations in thetRNA(Ser(UCN)) gene. Ann. Neurol. 44, 635-640

James AM, Wei YH, Pang CY, Murphy MP (1996) Altered mitochondrial functions in fibroblasts containing MELAS or MERRF mitochondrial DNA mutations. Biochem J 318:401-407

James AM, Sheard PW, Wei YH, Murphy MP (1999) Decreased ATP synthesis is phenotypically expressed during increased energy demand in fibroblasts containing mitochondrial tRNA mutations. Eur J Biochem 259:462-469

Kann O, Kovács R, Njunting M, Behrens CJ, Otahal J, Lehmann TN, Gabriel S, Heinemann U (2005) Brain 128:2396-2407

Kasamatsu H, Vinograd J. Replication of circular DNA in eukaryotic cells. Annu Rev Biochem. 1974;43(0):695-719. Review

Krajewski S, Krajewska M, Ellerby LM, Welsh K, Xie Z, Deveraux QL, Salvesen GS, Bredesen DE, Rosenthal RE, Fiskum G, Reed JC (1999) ProcNatlAcadSci USA 96:5752-5757

Kudin AP, Kudina TA, Seyfried J, et al. Seizure-dependent modulation of mitochondrial oxidative phosphorylation in rat hippocampus. Eur J Neurosci 2002;15:1105-14.

Kunz WS, Goussakov IV, Beck H, et al. Altered mitochondrial oxidative phosphorylation in hippocampal slices of kainate-treated rats. Brain Res 1999;826:236-42.

Kunz WS (2002) The role of mitochondria in epileptogenesis. CurrOpinNeurol 15:179-184 
Kunz WS, Kudin AP, Vielhaber S, Blümcke I, Zuschratter W, Schramm J, Beck H, Elger CE (2000) Ann Neurol 48:766-773

Liu CY, Lee CF, Wei YH (2009) Role of reactive oxygen specieselicited apoptosis in the pathophysiology of mitochondrial and neurodegenerative diseases associated with mitochondrial DNA mutations. J Formos Med Assoc 108:599-611

Leonard JV, Schapira AHV. Mitochondrial respiratory chain disorders I: mitochondrial DNA defects. Lancet 2000;355:299-304

Longo N. Mitochondrial encephalopathy.NeurolClin 2003;21:817-31.

Majamaa K, Moilanen JS, Uimonen S, Remes AM, Salmela PI, Karppa M, et al. Epidemiology of A3243G, the mutation for mitochondrial encephalomyopathy, lactic acidosis, and strokelike episodes: prevalence of the mutation in an adult population. Am J Hum Genet 1998;63:447- 54.

Manfredi, G., Schon, E.A., Moraes, C.T., Bonilla, E., Berry, G.T., Sladky, J.T., DiMauro, S.,1995. A new mutation associated with MELAS is located in a mitochondrial DNA polypeptide-coding gene. Neuromuscul.Disord. 5, 391-398.

Manfredi, G., Schon, E.A., Bonilla, E., Moraes, C.T., Shanske, S., DiMauro, S., 1996.Identification of a mutation in the mitochondrial tRNA(Cys) gene associated with mitochondrial encephalopathy. Hum. Mutat. 7, 158-163.

Mancuso, M., Filosto, M., Mootha, V.K., Rocchi, A., Pistolesi, S., Murri, L., DiMauro, S.,Siciliano, G., 2004. A novel mitochondrial tRNAPhe mutation causes MERRFsyndrome. Neurology 62, 2119-2121.

Minassian BA, Sainz J, Delgado-Escueta AV. Genetics of myoclonic and myoclonus epilepsies. ClinNeurosci1995;3:223-35.

Mitani M, Jinnai K, Takahashi K, Koide R, Tsuji S. A case of NARP (neurogenic muscle weakness, ataxia, and retinitispigmentosa) with a T-to-C point mutation at nt 8993 of mitochondrial DNA. ClinNeurol 2000;40:600-4.

Montirosso R, Brambilla D, Felisari G et al. Electrophysiological analysis of cognitive slowing in subjects with mitochondrial encephalomyopathy. J NeurolSci 2002;194:3-9.

Morten, K.J., Cooper, J.M., Brown, G.K., Lake, B.D., Pike, D., Poulton, J., 1993. A new pointmutation associated with mitochondrial encephalomyopathy. Hum. Mol. Genet. 2,2081-2087.

Naini, A.B., Lu, J., Kaufmann, P., Bernstein, R.A., Mancuso, M., Bonilla, E., Hirano, M.,DiMauro, S., 2005.Novel mitochondrial DNA ND5 mutation in a patient withclinical features of MELAS and MERRF. Arch. Neurol. 62, 473-476.

Naviaux RK, Nguyen KV (2004) Ann Neurol 55:706-712

Nishigaki, Y., Tadesse, S., Bonilla, E., Shungu, D., Hersh, S., Keats, B.J., Berlin, C.I.,Goldberg, M.F., Vockley, J., DiMauro, S., Hirano, M., 2003. A novel mitochondrialtRNA(Leu(UUR)) mutation in a patient with features of MERRF and Kearns-Sayresyndrome. Neuromuscul.Disord. 13, 334-340.

Nishimura Y., T. Yoshinari, K. Naruse, T. Yamada, K. Sumi, H. Mitani, T. Higashiyama, T. Kuroiwa, Active digestion of sperm mitochondrial DNA in single living sperm revealed by optical tweezers, Proc. Natl. Acad. Sci. U. S. A.103 (2006) 1382-1387.

Nishino, I., Komatsu, M., Kodama, S., Horai, S., Nonaka, I., Goto, Y.,1996. The 3260mutationin mitochondrial DNA can cause mitochondrial myopathy, encephalopathy, lacticacidosis, and strokelike episodes (MELAS). Muscle Nerve 19, 1603-1604. 
Ohinata J, Hasegawa T, Kohyama J. A case of childhood onset myoclonus epilepsy with ragged-red fibers - with special reference to various clinical manifestations. No To Hattatsu 2002;34:427-30.

Ojala D, Montoya J, Attardi G. tRNA punctuation model of RNA processing in human mitochondria. Nature. 1981 Apr 9;290(5806):470-4.

Ozawa M, Goto Y, Sakuta R, Tanno Y, Tsuji S, Nonaka I (1995) The 8,344 mutation in mitochondrial DNA: a comparison between the proportion of mutant DNA and clinico-pathologic findings. NeuromusculDisord 5:483-488

Patel MN. Oxidative stress, mitochondrial dysfunction, and epilepsy. Free Radic Res 2002;36:1139-46.

Pulkes, T., Liolitsa, D., Eunson, L.H., Rose, M., Nelson, I.P., Rahman, S., Poulton, J.,Marchington, D.R., Landon, D.N., Debono, A.G., Morgan-Hughes, J.A., Hanna, M.G., 2005. New phenotypic diversity associated with the mitochondrial tRNA(SerUCN)gene mutation. Neuromuscul.Disord. 15, 364-371.

Ravn, K., Wibrand, F., Hansen, F.J., Horn, N., Rosenberg, T., Schwartz, M., 2001. An mtDNAmutation, 14453G-NA, in the NADH dehydrogenase subunit 6 associated withsevere MELAS syndrome. Eur. J. Hum. Genet. 9, 805-809.

Reddy PH, Beal MF. Are mitochondria critical in the pathogenesis of Alzheimer's disease?Brain Res Brain Res Rev. 2005 Nov;49(3):618-32. Review.

Riggs JE, Schochet SS Jr, Fakadej AV et al. Mitochondrial encephalomyopathy with decreased succinate-cytochromec reductase activity. Neurology 1984;34:48-53.

.Roger AJ, Clark CG, Doolittle WF (1996) A possible mitochondrial gene in the earlybranching amitochondriateprotist Trichomonasvaginalis. ProcNatlAcadSci USA 93:14618-14622

Ruiz-PesiniE, C. Diez-Sanchez, M.J. Lopez-Perez, J.A. Enriquez, The role of the mitochondrion in sperm function: is there a place for oxidative phosphorylationor is this a purely glycolytic process? Curr.Top. Dev. Biol. 77 (2007) 3-19.

Sakuta, R., Nonaka, I., 1989. Vascular involvement in mitochondrial myopathy. Ann.Neurol. 25, 594-601.

Santorelli FM, Mak SC, El-Schahawi M, et al. Maternally inherited cardiomyopathy and hearing loss associated with a novel mutation in the mitochondrial DNA tRNALys gene (G8363A). Am J Hum Genet 1996; 58: 933-39.

Santorelli, F.M., Tanji, K., Kulikova, R., Shanske, S., Vilarinho, L., Hays, A.P., DiMauro, S.,1997. Identification of a novel mutation in the mtDNA ND5 gene associated withMELAS. Biochem.Biophys. Res. Commun. 238, 326-328.

Sato,W., Hayasaka, K., Shoji, Y., Takahashi, T., Takada, G., Saito, M., Fukawa, O.,Wachi, E.,1994. A mitochondrial tRNA(Leu)(UUR) mutation at 3,256 associated withmitochondrial myopathy, encephalopathy, lactic acidosis, and stroke-like episodes(MELAS). Biochem. Mol. Biol. Int. 33, 1055-1061.

Schwartz, M., J. Vissing, Paternal inheritance of mitochondrial DNA, N. Engl. J. Med. 347 (2002) 576-580.

Schon EA, Hirano M, DiMauro S. Molecular genetic basis of the mitochondrial encephalopathies. In: Schapira AHV, DiMauro S,editors. Mitochondrial disorders in neurology 2. Boston: Bufferworth Heinemann; 2002. p. 69-113.

Schuelke, M., Bakker, M., Stoltenburg, G., Sperner, J., von Moers, A., 1998.Epilepsiapartialis continua associated with a homoplasmic mitochondrial tRNA(Ser(UCN))mutation. Ann. Neurol. 44, 700-704.

Servidei S. Mitochondrial encephalomyopathies: gene mutation. NeuromusculDisord 2002;12:524-9. 
Shah NS, Mitchell WG, Boles RG. Mitochondrial disorders: a potentially under-recognized etiology of infantilespasms. J Child Neurol 2002;17:369-72.

Shoffner JM, Lott MT, Lezza A, Seibel P, Ballinger SW, Wallace DC. Myoclonic epilepsy and ragged-red fiber disease (MERRF) is associated with a mitochondrial DNA tRNALys mutation. Cell 1990; 61: 931-37.

Shoffner JM. Oxidative phosphorylation diseases. In: Scriver CR, Beaudet AL, Sly WS, Valle $\mathrm{D}$, editors. The metabolic and molecular bases of inherited disease, 8th ed. New York7 McGraw-Hill, 2001. p. 2367- 424.

Shtilbans, A., El-Schahawi, M., Malkin, E., Shanske, S., Musumeci, O., DiMauro, S., 1999.Anovel mutation in the mitochondrial DNA transfer ribonucleic acid Asp gene in a childwith myoclonic epilepsy and psychomotor regression. J. Child Neurol. 14, 610-613.

Shtilbans, A., Shanske, S., Goodman, S., Sue, C.M., Bruno, C., Johnson, T.L., Lava, N.S.,Waheed, N., DiMauro, S., 2000. G8363A mutation in the mitochondrial DNA transfer ribonucleicacidLys gene: another cause of Leigh syndrome. J. Child Neurol. 15,759-761.

Silvestri G, Moraes CT, Shanske S, Oh SJ, DiMauro S. A new mtDNA mutation in the tRNALys gene associated with myoclonic epilepsy and ragged-red fibers (MERRF). Am J Hum Genet 1992; 51: 1213-17.

Smeitink J, van den Heuvel L, DiMauro S. The genetics and pathology of oxidative phosphorylation. Nat Rev Genet 2001;2:342 - 52.

So N, Berkovic SF, Andermann F, Kuzniecky R, Gendron D, Quesney LF. Myoclonus epilepsy and ragged-red fibers (MERRF). Electrophysiological studies and comparison with the other progressive myoclonus epilepsies. Brain 1989; 112: 126176.

Spees, J. L., Olson, S. D., Whitney, M. J., Prockop, D. J., Mitochondrial transfer between cells can rescue aerobic respiration. PNAS 2006, 103, 1283 -1288.

Sutovsky, P., R.D. Moreno, G. Schatten, Ubiquitin tag for sperm mitochondria, Nature 402 (1999) 371-372.

Szewczyk, A.,Wojtczak, L., Mitochondria as a pharmacological target. Pharmacol. Rev. 2002, 54, 101-127.

Taniike, M., Fukushima, H., Yanagihara, I., Tsukamoto, H., Tanaka, J., Fujimura, H., Nagai,T., Sano, T., Yamaoka, K., Inui, K., 1992. Mitochondrial tRNA(Ile) mutation in fatalcardiomyopathy. Biochem.Biophys. Res. Commun. 186, 47-53.

Taylor, R.W., Chinnery, P.F., Haldane, F., Morris, A.A., Bindoff, L.A., Wilson, J., Turnbull,D.M., 1996. MELAS associated with a mutation in the valine transfer RNA gene ofmitochondrial DNA. Ann. Neurol. 40, 459-462.

Taylor, R.W., Singh-Kler, R., Hayes, C.M., Smith, P.E., Turnbull, D.M., 2001. Progressivemitochondrial disease resulting from a novel missense mutation in the mitochondrial DNA ND3 gene. Ann. Neurol. 50, 104-107.

Taylor, R.W., Schaefer, A.M., McDonnell, M.T., Petty, R.K., Thomas, A.M., Blakely, E.L.,Hayes, C.M., McFarland, R., Turnbull, D.M., 2004. Catastrophic presentation of mitochondrial disease due to a mutation in the tRNA(His) gene. Neurology $62,1420-1423$

Tiranti, V., Carrara, F., Confalonieri, P., Mora, M., Maffei, R.M., Lamantea, E., Zeviani, M.,1999. A novel mutation (8342G-NA) in the mitochondrial tRNA(Lys) geneassociated with progressive external ophthalmoplegia and myoclonus. Neuromuscul.Disord. 9, 66-71. 
Toyono M, Nakano K, Kiuchi M et al. A case of MERRF associated with chronic pancreatitis. NeuromusculDisord 2001;11:300-4.

Tsuji M, Kuroki S, Maeda H et al. Leigh syndrome associated with West syndrome. Brain Dev 2003;25:245-50.

Tzen CY, Wu TY, Liu HF. Sequence polymorphism in the coding region of mitochondrial genome encompassing position 8389-8865. Forensic Sci Int 2001;120: 204- 9.

Wallace DC (1999) Mitochondrial diseases in man and mouse. Science 283:1482-1488.

Wallace DC, Lott MT, Brown MD, Kerstann K. Mitochondria and neuro-ophthalmologic diseases. In: Scriver CR, Beaudet AL, Sly WS, Valle D, editors. The metabolic \& molecular bases of inherited disease, 8th ed. New York7 McGraw-Hill, 2001. p. 2425-509.

Wallace, D. C., A mitochondrial paradigm of metabolic and degenerative diseases, aging, and cancer: A dawn for evolutionary medicine. Annu. Rev. Genet. 2005, 39, 359 407.

Van Goethem G, Mercelis R, Lofgren A et al. Patient homozygous for a recessive POLG mutation presents with features of MERRF. Neurology 2003;61:1811-3.

Varlamov, D.A., Kudin, A.P., Vielhaber, S., Schröder, R., Sassen, R., Becker, A., Kunz, D.,Haug, D., Rebstock, J., Heils, A., Elger, C.E., Kunz,W.S., 2002. Metabolic consequencesof a novel missense mutation of the mtDNA CO I gene. Hum. Mol. Genet. 11,1797-1805.

Vellai T, Takács K, Vida G. A new aspect to the origin and evolution of eukaryotes.J MolEvol. 1998 May;46(5):499-507.

Veltri, K. L., Espiritu, M., Singh, G., Distinct genomic copy number in mitochondria of different mammalian organs. J. Cell. Physiol. 1990, 143, 160-164.

Virgilio R, Ronchi D, Bordoni A, Fassone E, Bonato S, Donadoni C, Torgano G, Moggio M, Corti S, Bresolin N, Comi GP (2009) Mitochondrial DNA G8363A mutation in the tRNALys gene: clinical, biochemical and pathological study. J NeurolSci 281:85-92, Review

Zeviani M, Di Donato S. Mitochondrial disorders. Brain 2004;127:2153-72.

Zeviani, M., Muntoni, F., Savarese, N., Serra, G., Tiranti, V., Carrara, F., Mariotti, C.,DiDonato, S.,1993. A MERRF/MELAS overlap syndrome associated with a new pointmutation in the mitochondrial DNA tRNA(Lys) gene. Eur. J. Hum. Genet. 1, 80-87.

Zsurka G, Baron M, Stewart JD, Kornblum C, Bös M, Sassen R, Taylor RW, Elger CE, Chinnery PF, Kunz WS (2008) J Neuropathol Exp Neurol 67:857-866

Zsurka G, Hampel KG, Nelson I, Jardel C, Mirandola SR, Sassen R, Kornblum C, Marcorelles P, Lavoué S, Lombès A, Kunz WS (2010) Neurology 74:507-512 


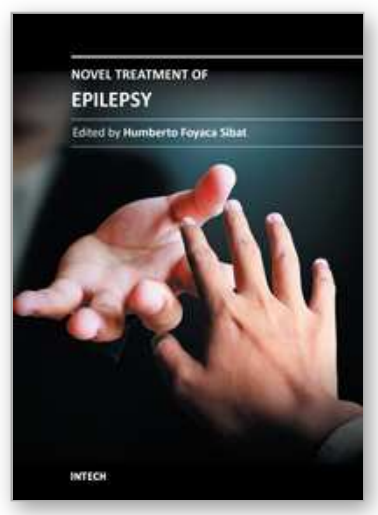

\author{
Novel Treatment of Epilepsy \\ Edited by Prof. Humberto Foyaca-Sibat
}

ISBN 978-953-307-667-6

Hard cover, 326 pages

Publisher InTech

Published online 22, September, 2011

Published in print edition September, 2011

Epilepsy continues to be a major health problem throughout the planet, affecting millions of people, mainly in developing countries where parasitic zoonoses are more common and cysticercosis, as a leading cause, is endemic. There is epidemiological evidence for an increasing prevalence of epilepsy throughout the world, and evidence of increasing morbidity and mortality in many countries as a consequence of higher incidence of infectious diseases, head injury and stroke. We decided to edit this book because we identified another way to approach this problem, covering aspects of the treatment of epilepsy based on the most recent technological results â€œin vitroâ€ from developed countries, and the basic treatment of epilepsy at the primary care level in rural areas of South Africa. Therefore, apart from the classic issues that cannot be missing in any book about epilepsy, we introduced novel aspects related with epilepsy and neurocysticercosis, as a leading cause of epilepsy in developing countries. Many experts from the field of epilepsy worked hard on this publication to provide valuable updated information about the treatment of epilepsy and other related problems.

\title{
How to reference
}

In order to correctly reference this scholarly work, feel free to copy and paste the following:

Massoud Houshmand (2011). Role of Mitochondria in Epilepsy, Novel Treatment of Epilepsy, Prof. Humberto Foyaca-Sibat (Ed.), ISBN: 978-953-307-667-6, InTech, Available from:

http://www.intechopen.com/books/novel-treatment-of-epilepsy/role-of-mitochondria-in-epilepsy

\section{INTECH}

open science | open minds

\section{InTech Europe}

University Campus STeP Ri

Slavka Krautzeka 83/A

51000 Rijeka, Croatia

Phone: +385 (51) 770447

Fax: +385 (51) 686166

www.intechopen.com

\section{InTech China}

Unit 405, Office Block, Hotel Equatorial Shanghai

No.65, Yan An Road (West), Shanghai, 200040, China

中国上海市延安西路65号上海国际贵都大饭店办公楼 405 单元

Phone: +86-21-62489820

Fax: $+86-21-62489821$ 
(C) 2011 The Author(s). Licensee IntechOpen. This chapter is distributed under the terms of the Creative Commons Attribution-NonCommercialShareAlike-3.0 License, which permits use, distribution and reproduction for non-commercial purposes, provided the original is properly cited and derivative works building on this content are distributed under the same license. 